\title{
Analysis of the quality control planning in residential construction projects in Spain
}

\section{Análisis de la planificación del control de calidad en proyectos de edificación residencial en España}

José Manuel Mesa Fernandez (Main and Contact Author)

Universidad de Oviedo. Escuela Politécnica de Ingeniería de Gijón. Asturias. +34 985104272. Campus de Viesques, 33208 Gijón, Asturias, Spain.

mesa@api.uniovi.es

César Pacios González

Universidad de Oviedo. Asturias.

cesar.pacios@api.uniovi.es

Valeriano Álvarez Cabal

Universidad de Oviedo. Escuela Politécnica de Ingeniería de Gijón. Asturias.

valer@api.uniovi.es

Joaquín Villanueva Balsera

Universidad de Oviedo. Escuela Politécnica de Ingeniería de Gijón. Asturias.

balsera@api.uniovi.es

Manuscript Code: 615

Date of Acceptance/Reception: 01.01.2016/08.05.2015

\section{Resumen}

A pesar de los esfuerzos derivados de la legislación española y la cada vez mayor implantación de los sistemas de gestión de calidad en las empresas del sector de la construcción, siguen apareciendo defectos de distinta naturaleza y gravedad, lo que genera las consiguientes quejas $y$ reclamaciones por parte del usuario final. Distintos factores de la planificación del control de calidad en los proyectos de edificación residencial en España son analizados en este trabajo. Para ello, después de identificar y clasificar los defectos más habituales, el trabajo se centra en analizar la etapa inicial de planificación del control de calidad. Con ese objetivo inicialmente se estudia el contenido de los modelos proporcionados por los Colegios Profesionales de Arquitectos a sus asociados. Posteriormente, a partir de una muestra representativa de proyectos de edificación residencial, se analiza y discute su aplicación en la práctica.

Palabras clave: edificación; residencial; control; calidad; planificación

\begin{abstract}
Despite the legal efforts and the major increase in the implementation of quality management control systems in construction companies in Spain, serious deficiencies of different nature keep appearing, with the subsequent claims and complaints reported by the final user. This study analyses different factors in the planning of quality control in residential construction projects in Spain. After identifying and classifying the most common deficiencies, the study is focused on analyzing the first stage of the quality control planning. First, the content of models provided by the Professional Associations of Architects to their associates are studied. Afterwards, based on a representative sample of residential construction projects, its practical application is analyzed and discussed.
\end{abstract}

Keywords: construction; residential; control; quality; planning

In recent years, the construction industry has experienced a growing interest on quality assurance. There are two main reasons that cause such increasing interest. First, customers and users are becoming more and more demanding, claiming for higher quality in those products which entail a major economic effort. On the other hand, companies have become progressively aware of the cost of non-quality products in the construction industry, which can be between $5 \%$ and $10 \%$ of the total cost of production (WS Atkins Consultants, 2001).

The Spanish legal framework for construction industry consists of the Building Planning Act (BPA, 1999) and the Technical Building Code (TBC, 2006) in relation to its technical performance. The Building Planning Act establishes the basic requirements for buildings and the obligations for the different agents involved. The legal protection of the users goes beyond the technical requirements of the building, establishing also an insurance policy. However, despite this regulation, the defects in new properties are still a general concern, which leads to a considerable amount of 
complaints at the Spanish Consumer Office. In the building industry and particularly in residential building, there are a series of "agents involved". The Spanish legislation (BPA, 1999) describes the following agents:

- Client or property developer: any natural or legal, public or private person who, individually or collectively, decide, encourage, program and finance with their own resources or those of others, the building of properties for selling, delivery or assignment to third parties.

- Designer: it is the agent who, on behalf of the client and under the corresponding technical and land legislations, designs the project.

- Contractor: it is the agent who is contractually agreed to the execution of the works, or part of them, accordingly to the project and the contract.

- Project manager: it is the agent who leads the project management team for the development of the works under technical, aesthetic, urban and environmental aspects, in accordance with the project design.

- Manager on site: the agent who is part of the project management team and leads on site the technical function of managing the execution of the works, and controls qualitatively and quantitatively the construction and quality of what is built.

- Entities of quality control of the building: those trained to provide technical assistance in verifying the quality of design, materials and execution of the work and its installations in accordance with the project and the applicable regulations.

- Testing laboratories for quality control of building: provide technical assistance, by conducting tests or service tests of the materials, systems or installations of a construction work.

- Product suppliers: manufacturers, storekeepers, importers and sellers of construction products. A "construction product" is the one manufactured for its permanent incorporation into a work including materials, semi-finished items, components and works or part thereof, both completed or under implementation.

- Owner - User: it is the natural or legal person, public or private, that will make use of the building, which may or may not coincide with the promoter. It is more or less the same concept as "final client".

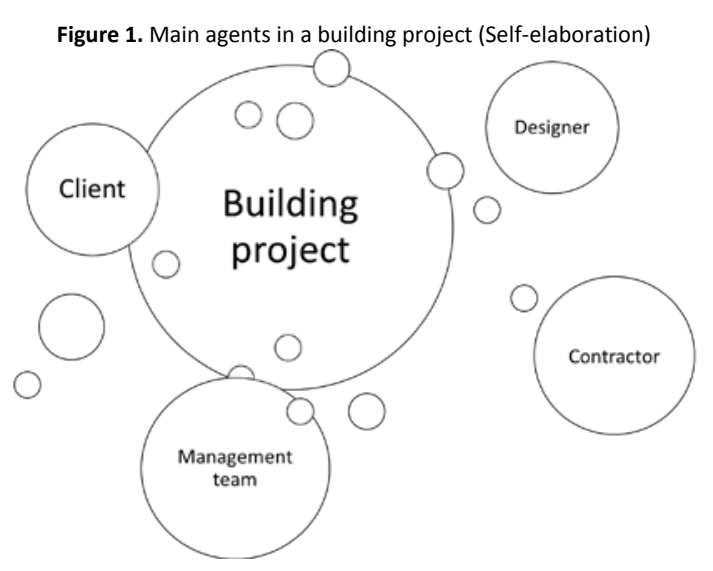

Generally speaking, bearing these actors in mind, the building process is generally performed as follows:

- Initially, the client contracts a team of designers to perform the viability study and the project with its specifications.

- After that, this client contracts one contractor for the execution of the works, who can outsource several services for their development.

- The execution of the works is supervised by the designer's team and the project management team, which is the same in most of the cases.

In this way of traditional contracting procedure in Spain, the quality is therefore based on direct inspection and is under direct responsibility of the project management team. The aim of this study is to analyze several aspects that currently involve the quality control in construction projects in Spain, considering the peculiarities of the sector, the influence of regulations and the relation between their application and the defects, which affect the buildings. To this purpose, first the most common defects in construction projects are collected. Afterwards, several reference models provided by professional associations to their associates are examined. And finally, their use and applications are analyzed in a sample of construction projects, and the conclusions are exposed. 
The defects on construction projects are always the highest concern for the quality control in the construction industry. There are many examples of definitions of the concept of construction defect (llozor, Okoroh, Egbu \& Archicentre, 2004), (Mills, Love \& Williams, 2009). However, one of the most thorough definition has been provided by (Watt, 1999), who defines a construction defect as "a failing or shortcoming in the function, performance, statutory or user requirements of a building and it might manifest itself within the structure, fabric, services or other facilities of the affected building".

It is also frequent to discriminate the phase where the defects are found, since these can appear during the construction phase (before the delivery of the building) or during its exploitation, in which case they are usually called construction faults and can be classified into:

- Apparent faults: construction flaws which appear soon after the handover of the property. A period of 12 months is usually fixed (Forcada et al., 2012). They are defects affecting the completion of the works that frighten the owners; however, they can be technically solved quite easily and at a low cost.

- Latent faults: these are construction defects that appear after the handover of the property, in an indefinite period, which affect the habitable conditions (waterproofing, soundproofing, insulation, etc.) or the stability of the building (foundation, structure or enclosures). These defects are generally difficult to repair and at a very high cost.

With the aim to reduce the defects, researchers have focused on the study and identification of the causes, extent and cost of construction defects, both at construction and exploitation phases. Most research studies are focused on defects on materials and systems, by examining different types of defects at given conditions and determining the methods for their detection. As a result, these studies are aimed at technical and technological issues (Chong \& Low, 2005).

Among the research studies which are trying to identify the root causes of the defects, Watt (1999) determined that the biological, meteorological and geochemical causes and other natural hazards, human activity, pollution, mismanagement, improper use, lack of maintenance and repair works are responsible for the vast majority of construction defects. This suggests that improper materials, wrong decisions and deficient repair works are the root causes of defects.

A most common cause of defects in property buildings is the high number of subcontractors in the execution phase. Therefore, the project manager tends to focus on coordination and cost management, leaving behind the monitoring of execution (Karim, Marosszeky \& Davis, 2006). This high level of subcontracting encourages inappropriate work practices by the subcontractors and implies long chains of command, which generates a low level of performance, communication and coordination (Tam, Shen \& Kong, 2011). In addition, new complications arise since most of the subcontractors involved are small businesses.

Another cause detected is the tendency of clients or property developers to entrust the execution of the works to the contractors submitting the lowest bid, and will remain accountable for the quality of the properties delivered (Karim, Marosszeky \& Davis, 2006). The research conducted by the Building Research Establishment (BRE, 1991) and (Richardson, 2002) concluded that the causes of construction defects have their origin in the weather conditions, the environmental conditions, a poorly designed project, chemical aggressions, structural movements (due to a wrongly structural design), the installation method, the workforce, maintenance and work conditions.

Bearing in mind the influence of project design and management as the root cause of defects, (Atkinson, 2002) determined that management errors represented more than $82 \%$ of all construction defects and that these errors always appear as latent defects, therefore not appearing in the construction phase. Austin, Baldwin and Steele (Austin, Baldwin \& Steele, 2002) showed the importance of integrating the planning of the design and control into the construction process, an also that the constructors are not able to develop a quality construction on their own, without the support of a clear and correct project design.

In Spain, Forcada (Forcada et al., 2012) focused their research on the defects that appear after the delivery of the property within 12 months. 2351 defects from seven property developments from 2004 to 2006 registered in the databases of four Spanish construction companies were analyzed. The analysis revealed that the most common defects were the omission of an element or task (37\%), defects related to poor finishing or appearance (19.5\%) and unsuitable installations (16.0\%).

Another relevant aspect is the implementation of quality management systems (QMS) in the construction sector in Spain based on ISO 9001 standard. In some cases, in Spain and in other countries, quality management systems have 
been combined with safety and the environmental systems (Giacomello, González \& Kern, 2014). Commercial reasons, image and marketing for clients against competitors, are the main motivations for QMS implementation, but not a better execution of the works (Del Castillo Peces, Mercado Idoeta, Prado Roman \& Del Castillo Peces, 2013).

From the perspective of claims and complaints, the Spanish Consumer Office (SCO, 2009) exposed that information requests and files of complaints in the property sector are third at the rank of all files of complaints registered, $8.93 \%$ of all the requests presented by the different consumers associations. The evolution of the complaints regarding the housing sector, if compared with the total of complaints from 1990 to 2009, shows that they were decreasing as years went by. In 1990, they represented $26.7 \%$, in 2000 15.9\%, until they reached $8.9 \%$ in 2009 . These indicators as well as the total number of claims related to the housing sector indicate that these have declined since the passing of the Technical Building Code (TBC, 2009).

\section{The quality control process in construction projects in Spain}

In Spain, according to article 10 of the Building Planning Act (Spain BPA, 1999), the designer must draft the housing project according to the current legislation and what was established in the contract with the client. Therefore, the designer has a legal liability to comply with the quality requirements previously defined and, at the same time, with the basic quality requirements established by the Building Planning Act (Spain BPA, 1999). Similarly, it is the designer's duty to include in the Project a Quality Control Plan as an attachment to the portfolio (according to Attachment I of Part I of the Technical Building Code (TBC, 2006)).

Articles 6, 7 and 8 of the Technical Building Code (TBC, 2006) establish the conditions to be met respectively:

- $\quad$ the project, verifying the compliance with the Technical Building Code and other applicable legislation, and its degree of definition, its quality and all aspects that may have an impact on the final quality of the building projected.

- $\quad$ work execution, establishing the targets and actions to perform to satisfy the correct control of:

- $\quad$ Product, equipment and systems (raw materials) delivery.

- $\quad$ Execution control

- $\quad$ Finished work control.

- $\quad$ the finished building must be obligatory checked (in addition to those which are voluntary) and service tests planned in the project or ordered by the project management team and under applicable legislation must be performed on the building as a whole, or on its parts and installations (partially or fully completed).

Therefore, the legal framework that governs the construction sector obliges the designer to draft a Quality Control Plan, which must be included in the project.

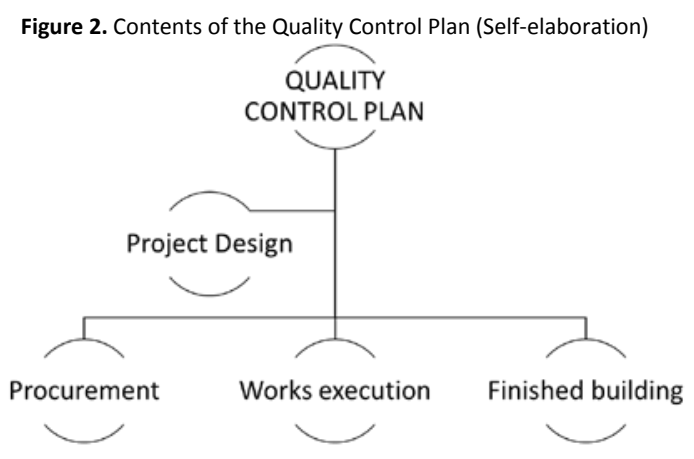

The control process should include firstly the control of the project itself, however, there is a clear legal void, since the object of control is defined but not the aspects that must be controlled, and neither who bears the responsibility to perform it. It is considered, therefore, relevant to the study to highlight the involvement in the quality control of each of the agents before, during and after the execution of the building. The following control processes must be oriented to material control, execution control and control of the finished building. The manager on site is the one that has the responsibility of programming and monitoring them.

Before the beginning of the works: The designer must define the content of the control to perform and the specifications to carry it out. The manager on site must be in charge of the quality control planning. The client must 
contract the trials and service tests with an accredited laboratory. The contractor must foresee the execution, delivery, sampling, testing and trial times.

During work execution: The project manager makes decisions coming from the control process. The manager on site manages the monitoring, adapting the programming to specific circumstances and pace of the work and commanding the performing of tests and specific trials, according to the quality control plan. The client is legally obliged to ensure the trials and tests are done and managed by the project management team. The contractor must provide the means to perform control tasks and service tests. The Quality Control Laboratories must deliver the results of their tests to the client and the manager on site. The product and systems suppliers must provide documentation and quality guarantees required for the products supplied.

Once the client delivers a building, the correct use and maintenance of the building, according to the instructions included in the Building Owner's Manual (a manual with technical, legal and administrative documentation), is under the responsibility of the users.

\section{Methodology}

The last chapter described how the process of control quality is performed in construction projects in Spain. This study first analyzes how the quality control planning is developed and performed and afterwards how it is implemented in real construction projects. The Professional Associations provide their collegiate with models and guidelines for drafting Quality Control Plans. Therefore, the first step of the analysis is to examine the criterion set by the Official Associations of Architects of Spain, in relation to the content of quality control plans. As a sample, the contents of the models of quality control plans provided by the Official Association of Architects in Galicia, Asturias, Madrid and Murcia to their members were analyzed. The key findings are the following:

- The four models of quality planning analyzed refer exclusively to the control of the procurement, control of the execution and control of the finished work. None of them mentions project design control.

- In all cases, they simply transcribe, more or less completely, the articles in the Technical Building Code about controls (TBC, 2006).

- None of the analyzed models specifically defined which tests to perform. In the procurement, control it is not determined which products, equipment or systems must be controlled, either by distinctive signs or by testing. In the execution control there is no reference to control sampling, types of controls or inspections, neither to the criteria for rejection or possible actions to be performed. In the control of the finished work it is neither specifically determined which tests must be performed.

- All models follow the control specifications as indicated in the project specifications or the "applicable law".

As previously indicated, the analysis continued with the study of a random sample of 15 quality control plans of residential building projects in Spain. The sample includes quality control plans for projects of different sizes, from single-family homes to large buildings. The distribution of projects, which are located in various geographical areas of Spain, can be considered as representative samples. Table 1 includes the number of dwellings, the approval year, the total built area (BA), the works budget (WB), the quality control budget (QCB) and the percentage of the works budget of every case analyzed which is devoted to quality control.

Table 1. General specifications of the 15 residential building projects (Self-elaboration)

\begin{tabular}{|l|c|r|r|r|r|c|}
\hline Project & Dwellings & \multicolumn{1}{|c|}{ Year } & \multicolumn{1}{|c|}{ BA $\left(\mathbf{m}^{\mathbf{2}}\right)$} & \multicolumn{1}{c|}{ WB $(\boldsymbol{\xi})$} & \multicolumn{1}{|c|}{ QCB (€) } & \% (QCB/WB) \\
\hline 1 & 47 & 2011 & 12.301 & 3.491 .131 & 34.950 & 1,00 \\
\hline 2 & 8 & 2011 & 392 & 399.360 & 5.990 & 1,50 \\
\hline 3 & 2 & 2012 & 412 & 190.500 & 525 & 0,28 \\
\hline 4 & 120 & 2011 & 11.016 & 7.280 .000 & 10.205 & 0,14 \\
\hline 5 & 2 & 2012 & 298 & 233.200 & 233 & 0,10 \\
\hline 6 & 22 & 2012 & 2.843 & 144.892 & 3.310 & 2,28 \\
\hline 7 & 11 & 2012 & 3.647 & 1.101 .297 & 4.762 & 0,43 \\
\hline 8 & 7 & 2011 & 855 & 383.660 & 0 & 0,00 \\
\hline 9 & 52 & 2010 & 10.155 & 3.923 .339 & 21.100 & 0,54 \\
\hline 10 & 22 & 2009 & 2.477 & 2.072 .239 & 60.000 & 2,90 \\
\hline 11 & 40 & 2009 & 6.345 & 2.560 .000 & 4.798 & 0,19 \\
\hline 12 & 15 & 2009 & 4.210 & 870.000 & 4.698 & 0,54 \\
\hline 13 & 24 & 2010 & 2.984 & 1.145 .839 & 22.917 & 2,00 \\
\hline 14 & 15 & 2011 & 3.125 & 1.292 .250 & 12.300 & 0,95 \\
\hline 15 & 11 & 2012 & 1.264 & 471.876 & 3.865 & 0,82 \\
\hline
\end{tabular}


From that sample, first it was studied the scope of the quality control plans, showing in Table 2 if elements are included in each phase or not.

\begin{tabular}{|c|c|c|c|c|}
\hline \multirow{2}{*}{ Project } & \multicolumn{4}{|c|}{ Quality control } \\
\hline & Design & Procurement & Execution & Finished work \\
\hline 1 & $x$ & $v$ & $v$ & $v$ \\
\hline 2 & $x$ & 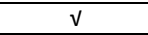 & $\mathrm{X}$ & $\mathrm{v}$ \\
\hline 3 & $x$ & $\mathrm{v}$ & $\mathrm{X}$ & $x$ \\
\hline 4 & $x$ & 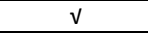 & $\sqrt{ }$ & $\checkmark$ \\
\hline 5 & $x$ & $v$ & $x$ & $x$ \\
\hline 6 & $x$ & $\mathrm{v}$ & $\mathrm{v}$ & $\mathrm{V}$ \\
\hline 7 & $x$ & $v$ & $x$ & $x$ \\
\hline 8 & $x$ & $\mathrm{~V}$ & $\mathrm{X}$ & $x$ \\
\hline 9 & $x$ & $\mathrm{v}$ & $\sqrt{ }$ & $\mathrm{V}$ \\
\hline 10 & $x$ & $v$ & 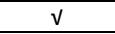 & $\mathrm{x}$ \\
\hline 11 & $x$ & $\mathrm{v}$ & $\sqrt{ }$ & $\sqrt{ }$ \\
\hline 12 & $x$ & 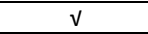 & $\mathrm{v}$ & $\checkmark$ \\
\hline 13 & $x$ & $\mathrm{~V}$ & $\mathrm{X}$ & $x$ \\
\hline 14 & $x$ & $\sqrt{ }$ & $\sqrt{ }$ & $x$ \\
\hline 15 & $x$ & $\mathrm{v}$ & $\sqrt{v}$ & $\mathrm{v}$ \\
\hline
\end{tabular}

The conclusions arising from the analysis of the scope of the content of quality control plans are the following:

- Most of them, the same as the models, are limited to transcribe more or less literally the articles from the Technical Building Code, which deal with quality control.

- As with the models of control plans provided by the Professional Association of Architects, all of them refer to the execution control exclusively, none of them mention project control at its design stage. All of them take into account the delivery control phase, but not the execution control phase and the control of the finished work.

- In a high percentage of cases, quality control plans analyzed include -for the products, equipment and systems delivery control - quality labels, a list of products, which must be labelled by the CE mark (Conformité Européenne).

- $\quad$ For the delivery control of products, equipment and systems by trials, many of the control plans include a full description of the types, samples and acceptance and rejection criteria, but exclusively for foundations and structures.

- The specifications for the execution control are simple references to the project specifications or the applicable legislation. The same occurs for the finished work control, there is no specification whatsoever to the service tests to perform.

None of the quality control plans analyzed include the budget for this description and it is therefore included as another item in the project budget. These budgets only include the tests from the delivery control and the finished work control.

Considering that quality control plan budgets only include the trials and service tests, it has been considered relevant to analyze on which items of the budget such controls are made, expressing the rate of economic relevance and the degree of specification (type, samples, acceptance and rejection criteria and actions to perform). All the construction units have been comprised in the chapters related to earthwork, foundation and structure, masonry, interior and exterior carpentry, installations, painting, urbanization and others. The table corresponding to one of the projects is included as an example (Table 3).

Table 3. Quality control and service tests for Project 1 (Self-elaboration)

\begin{tabular}{|c|c|c|c|c|c|c|c|}
\hline \multirow{4}{*}{ Project 1} & \multicolumn{7}{|c|}{ Quality control } \\
\hline & \multicolumn{5}{|c|}{ Execution control } & \multicolumn{2}{|c|}{ Finished building } \\
\hline & \multicolumn{5}{|c|}{ Tests } & \multicolumn{2}{|c|}{ Operation tests } \\
\hline & Type & Sampling & Criteria Accept/Reject & Actions & \% Budget & Description & \% Budget \\
\hline Earthmoving & $x$ & $x$ & $x$ & $x$ & 0 & $x$ & 0 \\
\hline Foundation and structure & $\mathrm{v}$ & $\mathrm{v}$ & $x$ & $x$ & 51,17 & $x$ & 0 \\
\hline Masonry & 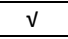 & $\mathrm{v}$ & $x$ & $x$ & 16,27 & $x$ & 0 \\
\hline Carpentry & $\mathrm{v}$ & $\mathrm{v}$ & $x$ & $x$ & 3,66 & $\mathrm{v}$ & 2,44 \\
\hline Facilities & $\mathrm{V}$ & $\mathrm{v}$ & $\mathrm{x}$ & $\mathrm{x}$ & 1,25 & $\mathrm{~V}$ & 25,21 \\
\hline Painting & $x$ & $x$ & $x$ & $x$ & 0 & $x$ & 0 \\
\hline
\end{tabular}




\begin{tabular}{|l|l|l|l|l|l|l|l|}
\hline Ext. finishes (Driveways, walkways, ...) & $\mathrm{X}$ & $\mathrm{X}$ & $\mathrm{X}$ & $\mathrm{X}$ & 0 & $\mathrm{X}$ \\
\hline Other & $\mathrm{X}$ & $\mathrm{X}$ & $\mathrm{X}$ & $\mathrm{X}$ & 0 & $\mathrm{X}$ \\
\hline
\end{tabular}

The analysis of the data collected lead to the following conclusions, taking into account that for the calculation of percentages only line item budgets were considered:

- The average quality control budget dedicated to testing (execution control) is $56.9 \%$, whereas $43.1 \%$ is dedicated to operation tests (finished work control).

- The highest percent from the $56.9 \%$ of the budget for trials is devoted to foundations and structure control, with an average value of $48.5 \%$ against $7.1 \%$ devoted to masonry, $1.1 \%$ devoted to carpentry and $0.2 \%$ devoted to facilities.

- $\quad$ The highest percent from the $43.1 \%$ for final testing is devoted to facility tests, with an average value of $42.8 \%$ against $0.3 \%$ devoted to carpentry.

- Only the types of test, samples to be taken and acceptance/rejection criteria are included for the foundations tests, but in no case it is included the actions to take in case of rejection.

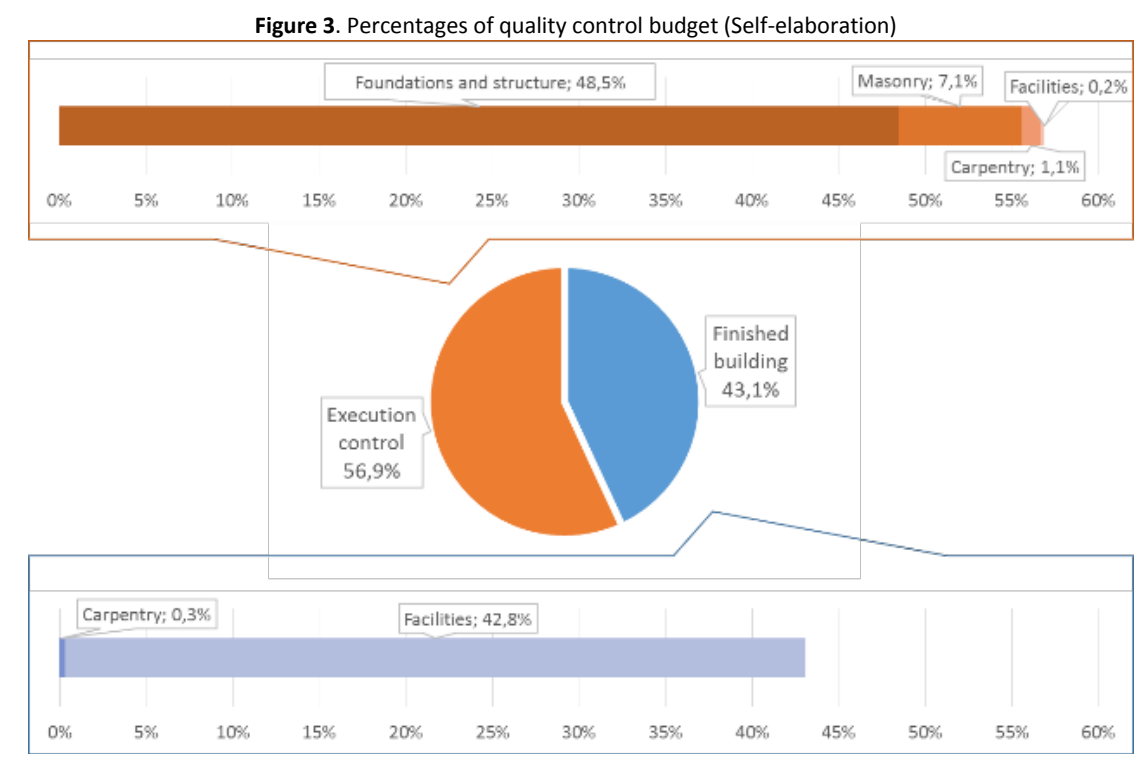

Discussion

As previously said, several studies have come to the conclusion that many of the defects derived from design errors. However, the existing regulation does not develop enough the control that must be carried out to ensure that the project, in that first design phase, meets the established requirements. In this sense, neither the aspects that should be controlled are determined, nor who bears the responsibility to implement them. As a consequence, neither the models for quality control plans provided by the professional associations, nor the control plans included as attachments to the projects analyzed make reference to project control at its initial design phase.

Regarding the execution control, as it has been found before, in most of the cases the designers include in their quality control plans just the text extracted from the regulations, with the approval of the professional associations. This results in an inaccurate definition of the elements or specific phases that must be controlled, both at the product delivery control as well as at the execution control, as for example the finished work control.

Within the delivery control through trials, it should be mentioned as an exceptional case the foundations and structures control, since it is common for these types of elements to describe the types of trials, samples and acceptance/rejection criteria. This circumstance comes from the mandatory regulation for control by testing of the elements of structural concrete and the serious technical and economic consequences of the defects on stability in buildings. It is for this reason mainly that the highest amount of investment for quality control is devoted to foundation and structures. In this sense it is also relevant to remark that since the passing of The Technical Building Code, it is mandatory for the client to take a ten-year insurance to cover structural damage (foundation, structure and envelop). The insurance company imposes the client to contract a Technical Inspection Body, which will be in charge of inspecting the design and execution of such elements. This is the only external inspection performed until the 
application for energy supplies once the building is finished. There is no doubt that as a result of emphasizing the inspection and control of these elements, the structural defects have been reduced (SCO, 2009).

As previously described, the responsibility of implementing execution control lies on the manager on site, who must control every project unit. There is an absence of specific guidelines on quality control plans on how to perform this task, which obliges to leave this quality control to the knowledge and expertise of the technician. This is obviously far from the main objective of the quality control plans. Moreover, in most of the cases the designer delegates his responsibilities of, for example, the quality control planning or the selection of the trials to perform, to the manager on site.

Finally, certain similarities between the foundation and structure controls and the control of the finished building appear after performing service tests. The control is stressed mainly on the installations, being almost economically equal to that of foundations and structures, which generally means there is no sign of defects related to installations when the time of delivering the building comes. One of the reasons for this planning is because several installations in the building are inspected by the supplier companies before the supply is actually delivered, or even by the public administration.

On the other hand, much less emphasis is made on controlling the finish quality, since the repairing of these sort of defects do not imply serious consequences, despite the usual complaints and dissatisfaction of the clients, which can undermine the good image of the contractor. The way to diminish the appearance of apparent defects is by performing a major control in the phase previous to delivery, especially by checking on the following issues: bathroom and kitchen supplies must be correct, surface finish tasks have been correctly performed, walls and floors are even, doors and windows can open correctly and installations must be fully finished (Forcada et al, 2014).

In the research presented in this paper it has been analyzed the parameters surrounding the planning of quality control in residential construction projects, whose peculiarities make it difficult to obtain quality projects. The following conclusions were reached:

- The number of agents involved in the construction process (which involves the fragmentation of work and the difficulty to control it), the project systems of development and contracting (whose responsibility lies with the different agents) and the peculiarities of each project (which hinder the transmission of knowledge and accumulated experiences) are examples of the difficulties that appear regularly in the development of any construction project. As a result, the appearance of defects both in the construction phase and the operational phase of buildings remain a recurrent problem.

- Despite the growing interest in the implementation of quality management systems in construction companies, it has been proved that it fails to ensure product quality, but focuses on the quality of management and the production process of the company. Therefore, its target moves away from the ultimate goal of quality assurance, which should include the satisfaction of the final customer or user.

- There is a legal void in the definition of the aspects that must be controlled in the design phase of the project, which means it is not planned or performed, despite several authors conclude that many of the defects that occur in the buildings have their origin in this phase.

- Although in legal terms the aspects related to control execution are developed, there is no planning at all. Attention is only is paid to delivery control of materials that make up the foundation and structure of the buildings, although these elements are subject to external additional control. The intensification of this control has resulted in a gradual decrease of the structural defects of the buildings.

- In the application of quality control in the implementation phase, it has also been observed a certain tendency to the intensification of control over those elements, parts or building systems that later will be controlled externally, such as installations, which, as a result, do not usually present defects. Following this same theory, it could be interesting to establish regulations on the external control of the finishes, just prior to the delivery of the building, since the multiple defects which users find when buying a house could be avoided. 
Atkinson, A. R. (2002). The pathology of building defects; a human error approach. Engineering, Construction and Architectural Management, 9(1), 53-61. http://doi.org/10.1108/eb021206

Austin, S. A., Baldwin, A. N., \& Steele, J. L. (2002). Improving building design through integrated planning and control. Engineering, Construction and Architectural Management, 9(3), 249-258. http://doi.org/10.1108/eb021220

BRE, B. R. E. (1991). Housing defects reference manual: The Building Research Establishment defect action sheets. E and FN Spon. Retrieved from http://books.google.es/books?id=hztSAAAAMAAJ

Chong, W. K., \& Low, S. P. (2005). Assessment of Defects at Construction and Occupancy Stages. Journal of Performance of Constructed Facilities, 19(4), 283-289. http://doi.org/10.1061/(ASCE)0887-3828(2005)19:4(283)

Del Castillo Peces, C., Mercado Idoeta, C., Prado Roman, C., \& del Castillo Peces, J. (2013). Motivations for implementing the ISO 9001 standard in the Spanish Construction Sector. In XXII AEDEM International Conference. Aalen, Germany. Retrieved from https://www.researchgate.net/publication/258499433_Motivations_for_implementing_the_ISO_9001_standard_in_the_Spanish_Constructio n_Sector

Forcada, N., Macarulla, M., Fuertes, A., Casals, M., Gangolells, M., \& Roca, X. (2012). Influence of Building Type on Post-Handover Defects in Housing. Journal of Performance of Constructed Facilities, 26(4), 433-440. http://doi.org/10.1061/(ASCE)CF.1943-5509.0000225

Forcada, N., Macarulla, M., Gangolells, M., \& Casals, M. (2014). Assessment of construction defects in residential buildings in Spain. Building Research and Information, 42(5), 629-640. http://doi.org/10.1080/09613218.2014.922266

Giacomello, H., Gonzalez, M. A. S., \& Kern, A. P. (2014). Implementation of an integrated management system into a small building company. Revista de La Construccion, 13(3), 10-18. Retrieved from http://rdlc.alerta.cl/index.php/rdlc/article/view/542

Ilozor, B. D., Okoroh, M. I., Egbu, C. E., \& Archicentre. (2004). Understanding residential house defects in Australia from the State of Victoria. Building and Environment, 39(3), 327-337. http://doi.org/10.1016/j.buildenv.2003.07.002

Karim, K., Marosszeky, M., \& Davis, S. (2006). Managing subcontractor supply chain for quality in construction. Engineering, Construction and Architectural Management, 13(1), 27-42. http://doi.org/10.1108/09699980610646485

Mills, A., Love, P. E., \& Williams, P. (2009). Defect Costs in Residential Construction. Journal of Construction Engineering and Management, 135(1), 12-16. http://doi.org/10.1061/(ASCE)0733-9364(2009)135:1(12)

Richardson, B. (2002). Defects and Deterioration in Buildings: A Practical Guide to the Science and Technology of Material Failure. New York: Taylor and Francis. Retrieved from https://books.google.co.uk/books/about/Defects_and_Deterioration_in_Buildings.html?id=_fxzG7E6UIYC

BPA Spain. (1999). Building Planning Act, Official State Gazette. (Ley 38/1999 de Ordenación de la Edificación (LOE). BOE. Ministry of the Presidency, Spain.

Tam, V. W. Y., Shen, L. Y., \& Kong, J. S. Y. (2011). Impacts of multi layer chain subcontracting on project management performance. International Journal of Project Management, 29(1), 108-116. http://doi.org/10.1016/j.ijproman.2010.01.005

Technical Building Code (TBC). (2006). Official State Gazette, Spain. Retrieved from https://www.boe.es/diario_boe/txt.php?id=BOE-A-2006-5515

Watt, D. (1999). Building Pathology: Introduction and Practice. Oxford: Blackwell. Retrieved from http://books.google.es/books?id=Kcl8oqGz6lsC

WS Atkins Consultants, Universidad de Navarra. (2001). El camino europeo hacia la excelencia en la construcción (1 edition). Madrid: Ed. Dossat. ISBN-10: 8495312506 